\title{
Description of the first-stage juveniles of Xiphinema cretense and $X$. herakliense - Distribution of Xiphinema and Longidorus species in olive orchards and grapevines in Crete, Greece
}

\author{
E.A. Tzortzakakis ${ }^{*}$, A. Archidona-Yuste ${ }^{2}$, C. Cantalapiedra-Navarrete ${ }^{2}$, I.G. Birmpilis', \\ E. Nasiou', J.E. Palomares-Rius ${ }^{2}$ and P. Castillo ${ }^{2}$
}

Summary The occurrence of nematodes of the family Longidoridae was investigated in soil samples collected from cultivated and wild olives and grapevines in Crete. The first-stage juveniles of $X i-$ phinema cretense and $X$. herakliense are described for the first time. The species $X$. israeliae, $X$. cretense, $X$. herakliense and Longidorus pseudoelongatus, previously recorded exclusively from olives in Crete, are herein reported in the rhizosphere of grapevines. Also L. iranicus is reported for the first time in cultivated olive, while $X$. italiae and $L$. closelongatus are reported for the first time in wild olive in Crete. Data on the occurrence of phytoparasitic nematode species in cultivated olives, wild olives and grapevines are updated with those previously published.

Additional keywords: Longidorus closelongatus, L. cretensis, L. iranicus, L. pseudoelongatus, X. israeliae

Olive tree and grapevine are the most important crops on the island of Crete, occupying 177,000 and 25,500 hectares, respectively. These represent about $22 \%$ for olive trees and $20 \%$ for grapevines of the total corresponding cultivated areas in Greece. In addition, wild olive trees are also located in some south coastal areas of the island.

Dagger and needle nematodes of the genera Xiphinema and Longidorus, respectively, include a number of large plant ectoparasitic nematode species with long life cycles. They cause damage to a wide range of fruit and vegetable crops as well as wild plants by their direct feeding on root cells and transmission of nepoviruses (Decraemer and Robbins, 2007; Taylor and Brown, 1997).

\footnotetext{
'Department of Viticulture, Vegetable Crops, Floriculture and Plant Protection, Institute of Olive Tree, Subtropical Crops and Viticulture, N.AG.RE.F., Hellenic Agricultural Organization-DEMETER, PO BOX 2228, 71003 Heraklion, Crete, Greece

2 Institute for Sustainable Agriculture (IAS), Spanish National Research Council (CSIC), Avenida Menéndez Pidal s/n, 14004 Córdoba, Campus de Excelencia Internacional Agroalimentario, ceiA3, Spain

* Corresponding author: etzortza@her.forthnet.gr
}

The presence of Xiphinema and Longidorus nematodes on cultivated and wild olive and grapevines in Crete was investigated by Tzortzakakis et al. $(2014,2015)$. The soil samples were collected from:

a) 101 olive orchards in Heraklion and Lasithi provinces,

b) 22 individual wild olive trees in Heraklion province and

c) 30 vineyards in Heraklion province and assigned to the Nematology Laboratory (affiliation of the $1^{\text {st }}$ author) by farmers for nematode diagnosis.

Five known Xiphinema species (viz. $X$. index, $X$. israeliae, $X$. italiae, $X$. pachtaicum and $X$. simile), five known Longidorus species (viz. L. closelongatus, L. cretensis, L. iranicus (synonym of $L$. moesicus), $L$. orientalis, and $L$. pseudoelongatus) and two newly described (for the first time) Xiphinema species (viz. $X$. cretense and $X$. herakliense) were found.

The current work presents supplementary data on the occurrence of Xiphinema and Longidorus nematodes on olive trees and grapevines in Crete based on additional soil samples, which were collected from:

a) the topotype locality (cultivated olive) of 
$X$. cretense (Tzortzakakis et al., 2014) and an olive orchard where $X$. herakliense had been found (Tzortzakakis et al., 2015), aiming at the detection of first-stage juveniles $\left(J_{1}\right)$ which could not be detected after repeated samplings at the original description of these species. This lifestage may have a practical significance when distinguishing species closely related (Hunt, 1995),

b) 45 olive orchards in Heraklion, Rethymno and Lasithi provinces and 14 individual wild olive trees in Heraklion province, different to the ones in Tzortzakakis et al. $(2014,2015)$ study and

c) 100 vineyards in Heraklion and Chania provinces and assigned to the Nematology Laboratory (affiliation of the $1^{\text {st }}$ author) by farmers for nematode diagnosis.

Soil sampling (for olive trees), nematode extraction, fixing and identification protocols were carried out as by Tzortzakakis et al. (2014, 2015).

\section{Description of $\mathrm{J}_{1} \mathrm{~s}$ of Xiphinema cretense and Xiphinema herakliense}

In both species, J s were positively identified by the position of the replacement odontostyle, which lies mostly within the odontophore, with the anterior tip near the base of the functional odontostyle (Figures 1, 2) (Hunt, 1995).

\section{Xiphinema cretense $\left(J_{1}\right)$}

Measurements $(n=5): L=1103 \pm 24.4$ (10831128) $\mu \mathrm{m} ; \mathrm{a}=51.7 \pm 1.8$ (50.4-53.7); $\mathrm{b}=4.3 \pm$ $0.3(4.0-4.6) ; c=22.9 \pm 1.3(22.1-24.4) ; c^{\prime}=3.2$ \pm 0.1 (3.1-3.3); odontostyle length $=55.3 \pm$ 0.5 (56.0-57.0) $\mu \mathrm{m}$; replacement odontostyle length = $73.2 \pm 1.2$ (73.0-75.0) $\mu \mathrm{m}$; odontophore length $=41.9 \pm 1.0(41.0-43.0) \mu \mathrm{m}$; lip region width $=7.7 \pm 0.5(7.5-8.5) \mu \mathrm{m}$; oral aperture-guiding ring distance $=38.7 \pm 4.0$ (34.0-41.5) $\mu \mathrm{m}$; tail length $=48.6 \pm 2.5$ (46.051.0) $\mu \mathrm{m}$; hyaline region at tail tip $=11.5 \pm$ 0.6 (11.0-12.0) $\mu \mathrm{m}$.

Description: Morphologically similar to adult specimens described by Tzortzakakis et al. (2014), apart from developed reproductive system, shorter body length, tail shape and presence of replacement odontostyle (Figure 1A). Anterior part characterized by position of replacement odontostyle just posterior to functional odontostyle, its tip touching or very close to base of functional odontostyle (Figure 1B). Bluntly conoid tail shape well curved dorso-ventrally with a slight dorsal depression at hyaline region level (Figures 1C-E).

\section{Xiphinema herakliense $\left(J_{1}\right)$}

Measurements $(n=1): L=1183 \mu \mathrm{m} ; a=42.3$; $b=5.0 ; c=27.5 ; c^{\prime}=3.0$; odontostyle length $=63.0 \mu \mathrm{m}$; replacement odontostyle length $=81.5 \mu \mathrm{m}$; odontophore length $=39.0 \mu \mathrm{m}$; lip region width $=8.0 \mu \mathrm{m}$; oral apertureguiding ring distance $=43.0 \mu \mathrm{m}$; tail length $=43.0 \mu \mathrm{m}$; hyaline region at tail tip $=20.0$ $\mu \mathrm{m}$.

Description: Only one specimen was found. General morphology agrees closely to adults specimens described by Tzortzakakis et al. (2015), except for its developed reproductive system, shorter body length in open C-shape, tail shape and presence of replacement odontostyle (Figure 2A). Anterior part characterized by position of replacement odontostyle into odontophore, just posterior to base of functional odontostyle (Figure 2B). Bluntly conoid tail shape well curved dorso-ventrally with a strong dorsal depression at hyaline region level (Figure 2C).

\section{Distribution of Xiphinema and Longido- rus species in cultivated olive, oleaster and grapevine}

In the soil samples of 45 olive orchards, three Xiphinema (viz. X. israeliae, $X$. italiae, and $X$. pachtaicum) and two Longidorus (viz. L. iranicus, and L. pseudoelongatus) species were found. In three out of the 14 wild olive tree sampling points, two Xiphinema (viz. X. herakliense and $X$. italiae), and one Longidorus species (viz. L. closelongatus) were found.

In the grapevine samples, the data on the presence of $X$. index, $X$. italiae and $X$. pachtaicum were not considered in this study, as these are quite common nematode species found on grapevine in Crete. However, in 12 out of the 100 examined grapevine soil 


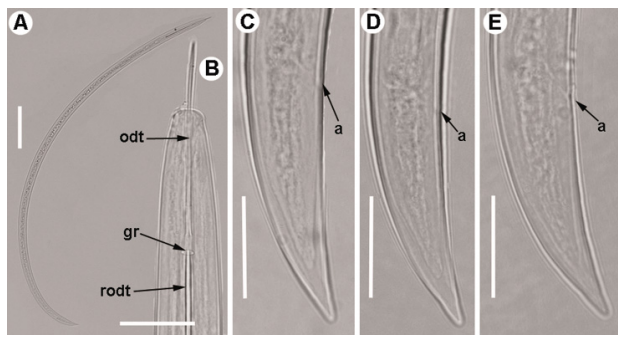

Figure 1. Light micrographs of first-stage juvenile of Xiphinema cretensis Tzortzakakis et al., 2014. A) Whole body. B) Anterior region showing odontostyle (odt), replacement odontostyle (rodt), and guiding-ring (gr). (-E) Tail regions showing anus (a). (Scale bars: $A=100 \mu \mathrm{m} ; B-E=20 \mu \mathrm{m})$.

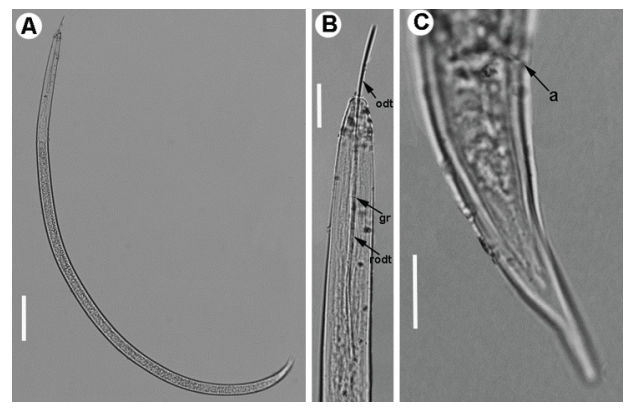

Figure 2. Light micrographs of first-stage juvenile of Xiphinema herakliense Tzortzakakis et al., 2015. A) Whole body. B) Anterior region showing odontostyle (odt), replacement odontostyle (rodt), and guiding-ring (gr). C) Tail region showing anus (a). (Scale bars: $A=100 \mu \mathrm{m} ; B=20 \mu \mathrm{m} ; C=10 \mu \mathrm{m})$.

Table 1. Longidoridae species found in cultivated olive (OLI), wild olive (OLE) and grapevine (GRA) in Crete.

\begin{tabular}{|c|c|c|}
\hline Nematode species & Plant, locality & Sample code \\
\hline Longidorus closelongatus Stoyanov 1964 & Grapevine, Xamoudochori & GRA36 \\
\hline Longidorus closelongatus & Grapevine, Ag Paraskies & GRA37 \\
\hline Longidorus closelongatus & Grapevine, Akrotiri & GRA39 \\
\hline Longidorus closelongatus & Wild olive, Agiofaraggo & OLE 34 \\
\hline Longidorus cretensis Tzortzakakis et al., 2001 & Grapevine, P. Elias & GRA34 \\
\hline Longidorus iranicus Sturhan and Barooti, 1983 & Olive, Arkalochori & OLI131 \\
\hline Longidorus iranicus & Grapevine, Archanes & GRA33 \\
\hline Longidorus iranicus & Grapevine, Ag. Thomas & GRA35 \\
\hline Longidorus iranicus & Grapevine, Roukani & GRA38 \\
\hline Longidorus iranicus & Grapevine, Lousakies & GRA31 \\
\hline Longidorus pseudoelongatus Altherr, 1976 & Olive, Arkalochori & OLI132 \\
\hline Longidorus pseudoelongatus & Olive, Faneromeni & OLI136 \\
\hline Longidorus pseudoelongatus & Grapevine, Gazi & GRA 32 \\
\hline Longidorus pseudoelongatus & Grapevine, P. Elias & GRA40 \\
\hline Xiphinema cretense Tzortzakakis et al., 2014 & Grapevine, P. Elias & GRA40 \\
\hline Xiphinema herakliense Tzortzakakis et al., 2015 & Wild olive, Agiofaraggo & OLE $33,34,36$ \\
\hline Xiphinema herakliense & Grapevine, P. Elias & GRA41 \\
\hline Xiphinema herakliense & Grapevine, P. Elias & GRA42 \\
\hline Xiphinema israeliae Luc et al., 1982 & Olive, Roufas & OLI14 \\
\hline Xiphinema israeliae & Olive, Neapoli & OLI115 \\
\hline Xiphinema israeliae & Olive, Pyrgiotisa & OLI138 \\
\hline Xiphinema israeliae & Olive, Dermatos & OLI145 \\
\hline Xiphinema israeliae & Olive, Dermatos & OLI146 \\
\hline Xiphinema israeliae & Grapevine, Akrotiri & GRA39 \\
\hline Xiphinema italiae Meyl, 1953 & Wild olive, Agiofaraggo & OLE 34 \\
\hline Xiphinema italiae & Olive, Episkopi & OLI 104 \\
\hline Xiphinema pachtaicum (Tulaganov, 1938) Kirjanova 1951 & Olive, 12 samples & * \\
\hline
\end{tabular}

*Sample codes $=101,102,103,105,107,110,123,129,130,137,139,140$

(c) Benaki Phytopathological Institute 
samples, three Xiphinema (viz. $X$. cretense, $X$. herakliense and $X$. israeliae) and four Longidorus species (viz. L. closelongatus, L. cretensis, L. iranicus, and L. pseudoelongatus) were found. Although L. moesicus was previously reported on grapevine in Crete (Tzortzakakis et al., 2014), after recent studies (Maafi et al., 2015), this species has been synonymized with Longidorus iranicus. All these data are presented in Table 1, which supplements previously published results (Tzortzakakis et al., 2014, 2015) for cultivated and wild olive trees and grapevines from Crete. Thus the updated records, considering also the previous studies, on the percentage of occurrence for the detected nematode species is as follows:

a) In 146 soil samples from olive orchards: L. closelongatus $1.4 \%, L$. cretensis $0.7 \%, L$. iranicus $0.7 \%$, L. pseudoelongatus $6.2 \%, X$. cretense $2 \%, X$. herakliense $0.7 \%, X$. index $2 \%, X$. israeliae $7.5 \%, X$. italiae $7.5 \%$ and $X$. pachtaicum $39 \%$,

b) In 36 soil samples from wild olive trees: $L$. closelongatus $2.8 \%, X$. herakliense $36.1 \%$, $X$. israeliae $2.8 \%, X$. italiae $2.8 \%$ and. $X$. pachtaicum $5.6 \%$,

c) In 130 samples from vineyards (excluding $X$. index, $X$. italiae and $X$. pachtaicum): L. closelongatus $5.4 \%$, L. cretensis $2.3 \%, L$. iranicus $6.2 \%$, L. orientalis $0.8 \%$, L. pseudoelongatus $1.5 \%$, $X$. cretense $0.8 \%, X$. herakliense $1.5 \%, X$. israeliae $0.8 \%$ and $X$. simile $0.8 \%$.

In conclusion, the data presented herein, indicate some new information for the presence of Longidoridae in Crete. Xiphinema israeliae, $X$. cretense, $X$. herakliense and $L$. pseudoelongatus were found on grapevine, while until now they had been found exclusively on olive trees; L. iranicus was found on cultivated olive trees, whereas until now it had been found only on grapevines; $X$. itali$a e$ and $L$. closelongatus are reported for first time on wild olive trees.

This research was supported by grant KBBE 219262 ArimNET-ERANET FP7 2012-2015 Project PESTOLIVE 'Contribution of olive history for the management of soilborne parasites in the Mediterranean basin' from Hellenic Agricultural Organization-DEMETER and Instituto $\mathrm{Na}$ cional de Investigación y Tecnología Agraria y Alimentaria (INIA), grant AGR-136 from 'Consejería de Economía, Innvovación y Ciencia' from Junta de Andalucía, and Union Europea, Fondo Europeo de Desarrollo regional, "Una manera de hacer Europa". I.G. Birmpilis and E. Nasiou were employed by the ARIMNET-PESTOLIVE project. The authors thank J. Martín Barbarroja and G. León Ropero from IAS-CSIC for the excellent technical assistance.

\section{Literature cited}

Altherr, E. 1976. La faune des eaux profondes interstitielles de la région de Wiesbaden. Bulletin de la Société Vaudoise des Sciences Naturelles, 73: 97-116.

Decraemer, W. and Robbins, R.T. 2007. The who, what and where of Longidoridae and Trichodoridae. Journal of Nematology, 39: 295-297.

Hunt, D.J. 1995. Aphelenchida, Longidoridae and Trichodoridae: Their Systematics and Bionomics. CAB International, Wallingford, U.K., p. 352.

Kirjanova, E.S. 1951. Soil nematodes found in cotton fields and in virgin soil of Golodnaya Steppe (Uzbekistan). Trudy Zoologie Institute Akademie Nauk SSSR, 9: 625-657.

Luc, M., Brown, D.J.F. and Cohn, E. 1982. Xiphinema israeliae n. sp. (Nematoda: Dorylaimoidea). Revue de Nématologie, 5: 233-239.

Maafi, Z.S., Subbotin, S.A., Sturhan, D., Barooti, S.and Taheri, Z.M. 2015. Characterisation of Longidorus iranicus Sturhan \& Barooti, 1983 (Nematoda: Longidoridae) from Iran and synonymisation of L. moesicus Lamberti, Choleva \& Agostinelli, 1983. Russian Journal of Nematology, 23: 21-28.

Meyl, A.H. 1953. Beitrage zur Kenntnis der Nematodenfauna vulkanisch erhitzter biotope. 1. Mitt., die terrikolen nematoden in bereich von fumarolen auf der insel ischia.Zeitschrift fuer Morphologie und Okologie der Tiere, 42: 67-116.

Stoyanov, D. 1964. A contribution to the nematofauna of the grapevine. Rastitelna Zashtita Sofia, 12: 16-24.

Sturhan, D. and Barooti, S.H. 1983. Longidorus iranicus n. sp. (Nematoda: Dorylaimida). Systematic Parasitology, 5: 21-24.

Taylor, C.E. and Brown, D.J.F. 1997.Nematode vectors of plant viruses. CABI, Wallingford, UK, p.296.

Tulaganov, A. T. 1938. The fauna of nematodes of cotton and surrounding soil in Katta-Kurgan district of the Uzbeck SSE. Tr Uzbekskistan Gos. 
University, 12: 1-25.

Tzortzakakis, E.A., Peneva, V., Terzakis, M., Neilson, R. and Brown, D.J.F. 2001. Longidorus cretensis $\mathrm{n}$. sp. (Nematoda: Longidoridae) from a vineyard infected with a foliar 'yellow mosaic' on Crete, Greece. Systematic Parasitology, 48: 131-139.

Tzortzakakis,E.A., Archidona-Yuste, A., Cantalapiedra-Navarrete, C., Nasiou, E., Lazanaki, M.S., Kabourakis, E.M., Palomares-Rius, J.E. and Castillo, P. 2014. Integrative diagnosis and molecular phylogeny of dagger and needle nematodes of olives and grapevines in the island of Crete, Greece, with description of Xiphinema cretense n. sp. (Nematoda, Longidoridae). European Journal of Plant Pathology, 140: 563-590.

Tzortzakakis,E.A., Archidona-Yuste, A., Cantalapiedra-Navarrete, C., Nasiou, Palomares-Rius, J.E. and Castillo, P. 2015. Description and molecular characterisation of Xiphinema herakliense $\mathrm{n} . \mathrm{sp}$. (Nematoda: Longidoridae) from wild and cultivated olives in Crete. Nematology,17: 231-245.

Received: 11 January 2016; Accepted: 20 May 2016

$\Sigma$ YNTOMH ANAKOIN $\Omega \Sigma \mathrm{H}$

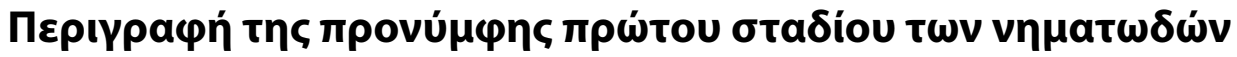

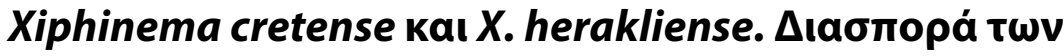

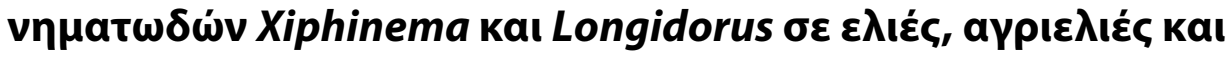 a
}

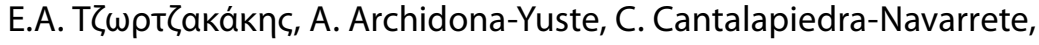

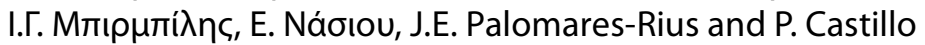

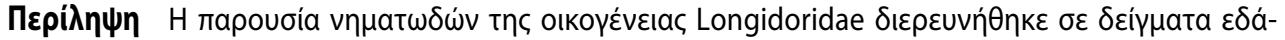

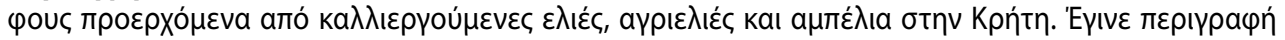

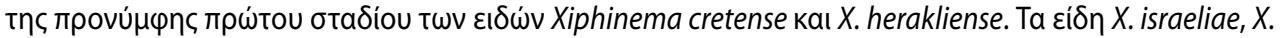

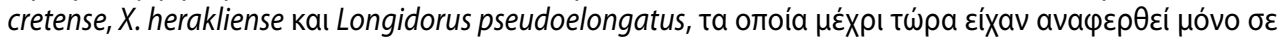

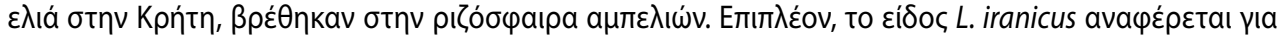

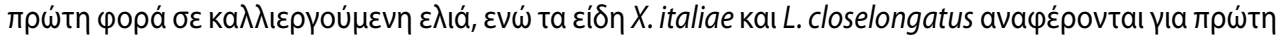

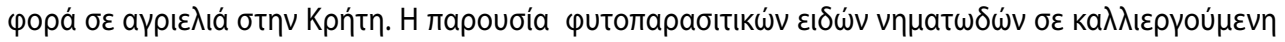

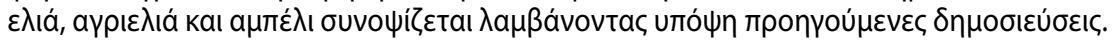

Hellenic Plant Protection Journal 9: 73-77, 2016

(c) Benaki Phytopathological Institute 